\title{
PERILAKU KOMUNIKASI VERBAL DAN NONVERBAL ANAK TUNAGRAHITA
}

\author{
Nova Yohana \\ Fakultas Ilmu Sosial dan Ilmu Politik \\ Jurusan Ilmu Komunikasi FISIP, Universitas Riau \\ Kampus Bina Widya Km. 12,5 Simpang Baru Pekanbaru 28293, telp/fax (0761)632677,35675 \\ email:yohana_nova@yahoo.com, HP: 081320033210 \\ Naskah diterima pada tanggal 3 Mei 2012, disetujui tanggal 21 November 2012
}

\section{VERBAL AND NON VERBAL COMMUNICATION BEHAVIOR OF CHILDREN WITH MENTAL RETARDATION}

\begin{abstract}
This study aimed to uncover how the self-concept and behavior of verbal and nonverbal communication of mental retardation children. The purpose of this study is to expose how self concept and verbal and nonverbal communication behavior of mental retardation children in interacting in the SDLB Negeri 041 Bangkinang environment. The method used is a qualitative method with symbolic interaction approach. To get the data, the authors used three data collection techniques, i.e. participant observation, in-depth interviews, and documentary study. The results of this study indicate that the concept of mental retardation children informant affected by "significant other" were categorized into two that is positive self-concept type of "social comparison" and negative self-concept type of "self-appraisal". Verbal communication of mental retardation children in interacting in the SDLB Negeri Bangkinang 041 are active with language deficits occur. Contrary, nonverbal communication of mental retardation children is more communicative that is used as a way to convey the message, complete, or confirm a verbal message, including when they show various emotional reactions when interacting in their social environment.
\end{abstract}

Keywords: Children with Mental Retardation, Self-concept, Verbal Communication, Nonverbal Communication, Symbolic Interaction.

\begin{abstract}
Abstrak
Penelitian ini dilakukan untuk memahami dan mendapatkan gambaran secara utuh mengenai realitas komunikasi pada anak tunagrahita. Penelitian ini bertujuan untuk mengungkap bagaimana konsep diri serta perilaku komunikasi verbal dan nonverbal anak tunagrahita dalam berinteraksi di lingkungan SDLB Negeri 041 Bangkinang tersebut. Metode yang digunakan adalah metode kualitatif dengan pendekatan interaksi simbolik. Untuk mendapatkan data, digunakan tiga teknik pengumpulan data, yaitu pengamatan berperan serta, wawancara mendalam, dan studi dokumentasi. Hasil penelitian menunjukkan bahwa konsep diri anak tunagrahita informan dipengaruhi oleh significant other yang dikategorikan menjadi dua, yaitu
\end{abstract}


konsep diri positif tipe social comparison dan konsep diri negatif tipe self appraisal. Komunikasi verbal anak tunagrahita dalam berinteraksi di lingkungan SDLB Negeri 041 Bangkinang bersifat aktif dengan defisit bahasa yang terjadi. Sebaliknya komunikasi nonverbal anak tunagrahita lebih bersifat komunikatif yang digunakan sebagai cara untuk menyampaikan pesan, melengkapi atau menegaskan pesan verbal, termasuk ketika mereka menunjukan berbagai reaksi emosi ketika berinteraksi di lingkungan sosialnya.

Kata Kunci: Tunagrahita, Konsep Diri, Komunikasi Verbal, Komunikasi Nonverbal, Interaksi Simbolik.

\section{PENDAHULUAN}

Keterbelakangan mental atau tunagrahita adalah salah satu bentuk gangguan yang dapat ditemui diberbagai tempat, dengan karakteristik penderitanya yang memiliki tingkat kecerdasan di bawah rata-rata, dan mengalami kesulitan dalam beradaptasi maupun melakukan berbagai aktivitas sosial di lingkungan sehingga mereka memerlukan pelayanan pendidikan khusus.

Sekolah Dasar Luar Biasa (SDLB) Negeri 041 Bangkinang merupakan salah satu pendidikan luar biasa di kota Bangkinang Kabupaten Kampar Provinsi Riau yang memberikan pendidikan bagi anak-anak yang mengalami ketunagrahitaan. Sangat dipahami oleh semua guru di SDLB Negeri 041 Bangkinang, bahwa anak tunagrahita memiliki IQ yang jauh di bawah rata-rata normal. Pada anak tunagrahita terdapat suatu disfungsi otak, sehingga kemampuannya terbatas hampir dalam semua fungsi yang mendasari proses kehidupannya. Keterbatasan kemampuan intelegensi atau kecerdasan di bawah rata-rata menyebabkan tunagrahita mempunyai beberapa kesulitan, diantaranya berhubungan dengan perilaku komunikasi.

Berbicara mengenai komunikasi berarti berbicara mengenai bahasa, baik verbal maupun nonverbal. Bahasa sebagai pesan komunikasi baik itu verbal maupun nonverbal membutuhkan kemampuan mengabstraksi yang dapat dipenuhi dengan kecerdasan intelegensi yang memadai. Berbeda dengan anak penyandang tunagrahita, apa yang dapat dilakukan oleh anak normal sulit diikuti oleh anak tunagrahita. Lanniari (2007) mengatakan seringkali stimulasi verbal maupun nonverbal dari lingkungannya sulit ditransfer dengan baik oleh anak tunagrahita karena keterbelakangan mental dan tingkat intelegensinya di bawah rata-rata. Bahkan hal-hal yang tampaknya sederhana terkadang tidak mampu dicerna dengan baik, sehingga dalam menghadapi anak-anak yang mengalami ketunagrahitaan, kita harus menyesuaikan diri dengan gaya komunikasi dan cara interaksi mereka. (http://phierda.wordpress.com)

Proses komunikasi tidak berjalan aktif dan interaktif, misalnya komunikasi yang terjadi sifatnya satu arah dan tidak ada umpan balik atau feedback, bahkan beberapa pertanyaan tidak direspon sama sekali, terkadang jawaban dari setiap pertanyaan yang diberikan tidak relevan atau tidak sesuai, bicara dengan singkat (tidak ada subjek predikatnya) sehingga lawan bicara sering tidak tahu apa maksudnya, lebih banyak menggunakan isyarat (menunjuk, mengangguk, menggeleng) daripada kata-kata dalam berkomunikasi. Ada pula yang hanya membentuk komunikasi melalui tersenyum, menangis, atau berbicara dengan menggunakan bahasa isyarat saja, dengan menunjukkan kartu bergambar atau kata-kata yang telah ditulis, anggukan, dan gelengan kepala untuk tanda "ya" dan "tidak" (bahasa isyarat yang sangat sederhana).

Meskipun anak-anak tunagrahita memiliki keterbatasan, namun tetap mereka adalah anak-anak yang sama seperti anak normal lainnya. Mereka juga ingin diakui, dihargai, dan diterima oleh lingkungan. Hal ini karena eksistensi diri dari anak tunagrahita juga sama dengan anak normal. Seperti di ketahui bersama bahwa di samping penilaian 
orang lain, eksistensi diri di lingkungan akan sangat berpengaruh pada konsep diri seseorang (http://elib.unikom.ac.id). Artinya konsep diri bukan merupakan faktor bawaan, melainkan berkembang dari pengalaman yang terus menerus dan terdiferensiasi. Dasar dari konsep diri individu itu ditanamkan pada saat-saat dini kehidupan anak yang akhirnya menjadi dasar yang memengaruhi tingkah lakunya dikemudian hari, termasuk ketika individu tersebut memberikan respon terhadap stimulus yang diterimanya dalam konteks komunikasi.

Sekolah merupakan salah satu tempat untuk melakukan proses sosial dengan lingkungan sekitar. Di sekolah anak tunagrahita bisa melakukan interaksi baik dengan guru, teman, atau bahkan orang lain. Dalam melakukan interaksi, terjadi suatu pertukaran simbol-simbol, dimana dalam simbol tersebut terkandung makna tersendiri yang hanya dipahami oleh anggotanya saja. Interaksi dengan melibatkan simbol-simbol disebut dengan interaksi simbolik. Interaksi yang melibatkan simbol-simbol yang bermakna ini akan memengaruhi individu dalam berperilaku. Interaksi simbolik yang dilakukan diantara anak tunagrahita secara perlahan akan memengaruhi dan juga mengarahkan perilaku mereka (http://elib.unikom.ac.id).

Bertolak dari uraian di atas, maka penulis perlu melakukan sebuah penelitian untuk mengkaji secara khusus mengenai perilaku komunikasi verbal dan nonverbal anak tunagrahita. Berdasarkan fakta dan keadaan yang telah diuraikan dalam konteks penelitian, maka fokus penelitian ini adalah: bagaimana perilaku komunikasi verbal dan nonverbal anak tunagrahita di SDLB Negeri 041 Bangkinang? dengan pertanyaan penelitian sebagai berikut: (1) bagaimana konsep diri anak tunagahita di SDLB Negeri 041 Bangkinang? (2) bagaimana komunikasi verbal anak tunagrahita dalam berinteraksi di lingkungan SDLB Negeri 041 Bangkinang? (3) bagaimana komunikasi nonverbal anak tunagrahita dalam berinteraksi di lingkungan SDLB Negeri 041 Bangkinang?

Adapun tujuan dari penelitian ini adalah: (1) memahami konsep diri anak tunagrahita di SDLB Negeri 041 Bangkinang; (2) mengetahui komunikasi verbal anak tunagrahita dalam berinteraksi di lingkungan SDLB Negeri 041 Bangkinang; mengetahui komunikasi nonverbal anak tunagrahita dalam berinteraksi di lingkungan SDLB Negeri 041 Bangkinang.

\section{LANDASAN KONSEP}

\section{Tinjauan Tentang Teori Interaksionisme Simbolik}

Manusia selalu melakukan interaksi dengan manusia lainnya. Dalam interaksi tersebut, terjadi pertukaran simbol-simbol baik itu verbal ataupun nonverbal. Dalam simbol-simbol atau lambang-lambang tersebut terdapat makna yang hanya dipahami oleh anggotanya saja. Makna ini akan sangat memengaruhi individu bertingkah laku atau berperilaku. Pendekatan atau teori yang mengakaji mengenai interaksi ini adalah interaksi simbolik. Interaksi simbolik dalam hal ini merupakan sebuah perspektif. Perspektif interaksi simbolik sebenarnya berada dibawah payung fenomenologis.

Para ahli perspektif interaksionisme simbolik melihat bahwa individu adalah objek yang bisa secara langsung ditelaah dan dianalisis melalui interaksinya dengan individu yang lain. Mereka menemukan bahwa individu-individu tersebut berinteraksi dengan menggunakan simbol-simbol, yang di dalamnya berisi tanda-tanda, isyarat dan katakata. Simbol atau lambang adalah sesuatu yang digunakan untuk menunjuk sesuatu lainnya, berdasarkan kesepakatan sekelompok orang. Lambang meliputi kata-kata (pesan verbal), perilaku nonverbal, dan objek yang disepakati bersama (Mulyana, 2005).

Salah satu tokoh perspektif interaksi simbolik adalah Mead. Inti interaksi simbolik menurut Mead adalah "diri". Mead menjelaskan bahwa kemampuan manusia untuk dapat merespon simbol-simbol diantara mereka ketika berinteraksi, membawa penjelasan interaksionisme simbolik kepada konsep tentang diri (self). Mead menjelaskan bahwa secara sosial seseorang dapat 
melakukan tindakan kepada dirinya sendiri, seperti kepada orang lain. Dia dapat memuji dirinya, menyalahkan dirinya atau mendorong dirinya sendiri; dia berbagi dirinya dengan dirinya sendiri, menghukumi diri oleh dirinya sendiri dan seterusnya. Dengan kata lain, seseorang dapat menjadikan dirinya sebagai objek tindakan dirinya sendiri. Diri terbentuk dengan cara yang sama sebagai objek, melalui "definisi"yang dibuat bersama orang lain.

Manusia selalu mengadakan interaksi, begitu pula anak-anak tunagrahita yang berinteraksi dengan keluarga maupun masyarakat sekitarnya. Dalam penelitian ini, peneliti menggunakan pendekatan melalui teori interaksi simbolik untuk mengetahui konsep diri anak tunagrahita, dan untuk mengetahui bentuk interaksi baik verbal maupun nonverbal anak-anak tunagrahita.

Komunikasi dengan menggunakan lambang verbal (komunikasi verbal) terjadi ketika anak tunagrahita menggunakan kata, baik itu melalui bahasa lisan maupun tulisan. Komunikasi nonverbal adalah ketika anak tunagrahita menggunakan simbol selain katakata seperti nada bicara, ekspresi wajah, dsb (Kuswarno, 2009). Meskipun simbol-simbol yang digunakan sangat sederhana akan tetapi sangat berpengaruh bagi anak tunagrahita, karena simbol yang mereka gunakan memiliki karakteristik dan juga kekhasan bagi anak tunagrahita. (http://elib.unikom.ac.id)

\section{Komunikasi Verbal}

Komunikasi verbal adalah komunikasi yang menggunakan kara-kata, entah lisan maupun tertulis. Komunikasi ini paling banyak dipakai dalam hubungan antar manusia. Melalui kata-kata, mereka mengungkapkan perasaan, emosi, pemikiran, gagasan atau maksud mereka, menyampaikan fakta, data, dan informasi serta menjelaskannya, saling bertukar perasaan dan fikiran, dan lain sebagainya. Benjamin L. Whorf mengemukakan:

"Bahasa adalah pandu realitas sosial. Walaupun bahasa biasanya tidak dianggap sebagai hal yang sangat diminati ilmuwan sosial, bahasa secara kuat mengondisikan pikiran kita tentang masalah dan proses sosial. Manusia tidak hanya hidup dalam dunia objektif, tidak hanya dalam dunia kegiatan sosial seperti yang biasa dipahaminya, tetapi ia sangat ditentukan oleh bahasa tertentu yang menjadi medium pernyataan bagi masyarakatnya. Tidak ada dua bahasa yang cukup sama untuk dianggap mewakili kenyataan sosial yang sama. Dunia tempat tinggal masyarakat, bukan sematamata dunia yang sama dengan merek yang berbeda" (Mandelbhaum, 1949 dalam Rakhmat, 1999).

\section{Komunikasi Nonverbal}

Ray L Birdwhistell mengatakan bahwa $65 \%$ dari komunikasi tatap muka adalah nonverbal. Sementara menurut Albert Mehrabian, 93\% dari semua makna sosial dalam komunikasi tatap muka diperoleh dari isyarat-syarat nonverbal (Tubbs \& Moss, 2005). Proses komunikasi yang menggunakan pesan nonverbal, yaitu meliputi semua pesan yang disampaikan tanpa kata-kata atau selain dari kata-kata yang kita pergunakan. Pesan ini meliputi seluruh aspek nonverbal dalam perilaku kita: ekspresi wajah, sikap tubuh, nada suara, gerakan tangan, cara berpakaian, dan lain sebagainya (Mulyana, 2006).

\section{Tinjauan Konsep Diri Dari Aspek Psikologis}

William D. Brooks mendefinisikan konsep diri sebagai "those physical, social, and psychological perceptions of ourselves that we have derived from experience and our interaction wtih others" (Rakhmat, 2001) atau dengan kata lain konsep diri adalah persepsi tentang diri kita yang bersifat fisik, psikologi, maupun sosial. Persepsi diri yang bersifat fisik meliputi penampilan, bentuk atau potongan tubuh. Sementara yang bersifat psikologis meliputi karakter kita, keadaan hati kita, hal-hal yang disenangi atau yang dibenci, yang terakhir yaitu persepsi diri yang bersifat sosial menyangkut hubungan atau interaksi kita dengan orang lain.

Konsep diri tidak begitu saja ada dalam diri individu. Konsep diri berkembang secara perlahan melalui proses yang panjang sejak usia dini. Secara umum menurut Loudon dan Britta (dalam Fitts 1984) 
perkembangan konsep diri bisa dilihat dari beberapa sudut pandang, yaitu:

\section{Self Appraisal}

Pendekatan ini mengemukakan bahwa konsep diri terbentuk dari bagaimana individu itu memandang dirinya sendiri. Konsep diri berkembang berdasarkan polapola perilaku yang paling dominan.

2. Reflected Appraisal

Konsep diri terbentuk berdasarkan penilaian yang didapatkan dari luar atau lingkungan sekitarnya.

\section{Social Comparison}

Pendekatan ini merupakan gabungan dari dua buah pandangan yang menyatakan bahwa konsep diri terbentuk dari apa yang dirasakan mengenai dirinya sendiri dengan apa yang dinilai oleh orang lain terhadap dirinya.

\section{Based Scanning}

Konsep diri terbentuk melalui proses pencarian, legalitas dari lingkungan terhadap aspirasi yang dimiliki individu.

Jadi melalui konsep diri individu mungkin secara tidak sadar akan menunjukkan reaksi-reaksi pengamatan, pemikiran, penilaian, serta mempertahankan atau menyempurnakan diri. Secara sadar pula individu dapat memiliki suatu konsepsi mengenai dirinya sendiri, sedangkan secara tidak sadar dia mungkin memiliki konsepsi yang berlawanan dengan konsepsi sadarnya tersebut. Dengan demikian, konsep diri setiap individu sangat ditentukan oleh bagaimana orang lain melihat/menilai dirinya saat berinteraksi.

\section{Tinjauan Tunagrahita}

Tunagrahita adalah istilah yang digunakan untuk menyebut anak yang memiliki kemampuan intelektual di bawah rata-rata. Tunagrahita sering disamakan dengan istilah-istilah berikut, yaitu: Lemah Pikiran, Terbelakang Mental, Bodoh, Dungu, Idiot, Tolol, Oligofrenia, Ketergantungan Penuh, Cacat Mental, dan Gangguan Intelektual. Dalam kepustakaan bahasa asing digunakan istilah-istilah mental retardation, mentally retarded, mental deficiency, mental defective, dan lain-lain. Istilah tersebut sesungguhnya memiliki arti yang sama yang menjelaskan kondisi anak yang kecerdasannya jauh di bawah rata-rata dan ditandai oleh keterbatasan intelegensi dan ketidakcakapan dalam interaksi sosial (Somantri, 2007). Kecerdasan dibawah ratarata normal ini menyebabkan tunagrahita mempunyai kesulitan sedikitnya pada empat kawasan yang berkaitan dengan atensi (attention), daya ingat (memory), bahasa (language), dan akademik (academics) (Hallahan \& Kauffman, 1991 dalam Delphie, 2006).

Tunagrahita memang memiliki karakter individual yang khas. Namun demikian, para ahli mencoba menglasifikasikan anak tunagrahita berdasarkan rentang IQ. Untuk mengetahui rentang IQ tunagrahita bisa dilakukan dengan cara tes dengan menggunakan skala Binet atau skala Wechsler. Adapun klasifikasi anak tunagrahita berdasarkan rentang IQ yaitu sebagai berikut:

\section{Tunagrahita Ringan}

Anak pada kelompok ini adalah anak yang memiliki rentang IQ 68-52 pada skala Binet dan 69-59 pada skala Wechsler. Anak dengan tunagrahita ringan ini mengalami keterbelakangan dalam hal belajar. Anak dengan tunagrahita ringan seperti anak normal pada umumnya, memiliki kemampuan berbicara, bisa diwawancarai dan sebagainya. Secara fisik, mereka juga memiliki fisik sama dengan anak normal pada umumnya.

2. Tunagrahita Sedang

Anak pada kelompok ini memiliki rentang IQ yaitu 51-36 pada skala Binet dan 54-40 pada skala Weschler. Anak dengan tunagrahita sedang hanya bisa menghitung sampai dengan angka 10, dan juga lambat dalam mengembangkan pemahaman dan penggunaan bahasa. Jika dilakukan pelatihan, pengawasan, dan juga pendidikan secara terus-menerus maka anak tunagrahita ini bisa melakukan pekerjaan sederhana sendiri. 
3. Tunagrahita Berat

Anak pada kelompok ini memiliki rentang IQ yaitu 32-20 pada skala Binet. Sedangkan untuk skala Weschler rentang IQ-nya yaitu 39-25. Anak dengan tunagrahita berat memiliki prestasi yang sangat rendah. Mengalami kesulitan dalam motorik halus dan motorik kasar. Anak tunagrahita berat juga sering disebut idiot.

4. Tunagrahita Sangat Berat

Anak pada kelompok ini memiliki IQ dibawah 19 pada skala Binet dan berada dibawah 25 pada skala Weschler. Anak dengan penyandang tunagrahita sangat berat perlu perawatan dan pengobatan dari dokter. Anak dengan penyandang tunagrahita sangat berat memiliki karakter fisik yaitu tipe muka mongoloid, mata sipit, hidung pesek dan sebagainya. (http://elib.unikom.ac.id)

\section{METODE PENELITIAN}

Penelitian ini menggunakan metode kualitatif yang bermaksud untuk memahami fenomena tentang apa yang dialami oleh subjek penelitian misalnya perilaku, persepsi, motivasi tindakan, dll., secara holistik, dan dengan cara deskripsi dalam bentuk kata-kata dan bahasa, pada suatu konteks khusus yang alamiah dan dengan memanfaatkan berbagai metode alamiah (Moleong, 2007).

Dalam penelitian ini, peneliti memilih interaksi simbolik sebagai pendekatan metode penelitian untuk memahami makna perilaku komunikasi verbal dan nonverbal anak tunagrahita yang perkembangannya sangat dipengaruhi konsep diri tunagrahita tersebut. Seperti dinyatakan oleh Blumer (dalam Basrowi dan Sukidin, 2002), metodologi yang dianut dalam pendekatan interaksi simbolik memiliki karakter yang khas dalam meneliti perilaku manusia. Proposisi paling mendasar dari interaksionisme simbolik adalah bahwa perilaku dan interaksi manusia itu dapat diperbedakan karena ditampilkan lewat simbol dan maknanya

Subjek penelitian pada penelitian ini adalah anak tunagrahita informan sebanyak 6 (enam) orang dengan tingkat ketunagrahitaan yang berbeda-beda di sekolah dasar luar biasa (SDLB) Negeri 041 Bangkinang. Informan kunci penelitian ini adalah anak tunagrahita beserta orang tua anak tunagrahita tersebut dan guru kelas, sedangkan informan pendukung adalah kepala sekolah, wakil kepala sekolah, guru, narasumber ahli pendidikan anak tunagrahita dan ahli psikologi. Aspek komunikasi yang menjadi objek penelitian ini adalah perilaku komunikasi verbal dan nonverbal anak tunagrahita dalam berinteraksi di lingkungan Sekolah Dasar Luar Biasa. Komunikasi verbal meliputi pesan lisan dan tulisan yang digunakan anak tunagrahita dalam kehidupan sehari-harinya, sedangkan komunikasi nonverbal meliputi penampilan fisik, komunikasi tubuh (gerakan tubuh, gerakan wajah, gerakan mata), komunikasi ruang, kewilayahan, dan sentuhan. Untuk mendapatkan data, penulis menggunakan tiga teknik pengumpulan data, yaitu: pengamatan berperan serta, wawancara mendalam, dan studi dokumentasi.

\section{HASIL DAN PEMBAHASAN}

\section{Konsep Diri Anak Tunagrahita}

Konsep diri merupakan aspek penting dalam diri seseorang, karena konsep diri merupakan gambaran yang dimiliki seseorang tentang dirinya yang dibentuk melalui pengalaman-pengalaman yang diperoleh dari interaksi dengan lingkungan. Konsep diri bukan merupakan faktor bawaan, melainkan berkembang dari pengalaman yang terus menerus dan terdiferensiasi. Menerangkan konsep diri melalui teori interaksi simbolik berarti melihat perilaku dan interaksi subjektif manusia dalam konteks penggunaan dan penafsiran simbol-simbol bermakna (Littlejohn, 1996).

Pada dasarnya komunikasi digunakan untuk menciptakan atau meningkatkan aktifitas hubungan antar manusia atau kelompok yang dipengaruhi oleh konsep diri, demikian pula yang terjadi pada tunagrahita seperti yang diungkapkan Samsunuwiyati 


\section{Tabel 1}

Kategori Konsep Diri Informan Tunagrahita

\begin{tabular}{ccc}
\hline No. & Kategori & Frekuensi \\
\hline 1 & Konsep diri positif & 5 \\
2 & Konsep diri negatif & 1 \\
\hline
\end{tabular}

Sumber: Hasil Penelitian April 2009-Oktober 2009

Mar'at narasumber ahli psikologi bahwa: "Konsep diri yang terbentuk pada diri siswa penyandang tunagrahita itu berbeda-beda. Konsep diri siswa-siswa ini paling besar terbentuk dari faktor lingkungan keluarga dan lingkungan sekitar siswa tersebut sejak lahir" (Wawancara dengan Samsunuwati Mar'at, 12 September 2009).

Pernyataan Samsunuwiyati Mar'at juga diperkuat oleh Zainal Alimin narasumber ahli pendidikan anak tunagrahita: "Faktor lingkungan sangat memengaruhi siswa dalam berkomunikasi dan bersosialisasi dengan teman-temannya maupun dengan orang lain. Jadi bukan hanya faktor belajar mengajar di sekolah saja yang dapat memengaruhi konsep diri siswa menurut pengalaman saya, ya menurut kenyataan di sini" (Wawancara dengan Zainal Alimin, 10 November 2009).

Dari hasil wawancara dan pengamatan diketahui informan tunagrahita mana yang mempunyai konsep diri positif maupun negatif. Hasil penelitian mengenai konsep diri tersebut dapat dikelompokkan seperti pada Tabel 1.

Informan yang memiliki konsep diri positif diantaranya $\mathrm{MZ}, \mathrm{GU}, \mathrm{RA}, \mathrm{MH}$, dan MA. Mereka dikatakan memiliki konsep diri positif karena ketika berada di lingkungan, mereka yakin akan kemampuannya mengatasi masalah, merasa setara dengan orang lain, menyadari setiap orang mempunyai berbagai perasaan, mempunyai keinginan dan perilaku yang disetujui orang lain, mampu memperbaiki dirinya karena sanggup mengungkapkan aspek-aspek kepribadiannya yang tidak disenanginya dan berusaha mengubahnya.
Hanya satu orang yang memiliki konsep diri yang negatif yang ditunjukkan dengan tidak terlalu mau melibatkan diri di lingkungan yang dirasakan berbeda dengan kondisi ketunagrahitaannya yaitu AL. Informan tunagrahita AL ketika berinteraksi di lingkungan sosial lebih banyak diam tidak percaya diri, atau tingkah laku yang ditampilkan berhubungan dengan kekurangan yang dipersepsinya secara subjektif dan kesadaran dirinya menjadi tidak realistis. Walaupun demikian AL masih bisa berinteraksi dengan baik walaupun interaksi interpersonal yang dibinanya masih bersifat pasif. Selain itu informan yang memiliki konsep diri negatif memiliki ciri-ciri yaitu melihat diri sendiri sebagai orang yang kurang memadai, mempersepsikan teman sebaya dan orang dewasa sebagai orang yang kurang dapat diterima, memperlihatkan pendekatan yang kurang efektif terhadap pemecahan masalah, memperlihatkan kebebasan yang kurang, ekspresi emosional yang kurang memadai, lebih banyak mengekspresikan perasaan diri negatif.

Informan tunagrahita sebagai makhluk sosial juga memiliki konsep diri meskipun konsep diri yang dimilikinya hanya sebatas ego anak-anak yang belum mengerti konsep diri negatif atau positif. Namun demikian, mereka tetap memiliki ego dan konsep diri yang berkembang sejak kecil yang dipengaruhi oleh pola asuh orang tua, hanya saja dengan keterbelakangan mentalnya agak terlambat dan membuatnya berbeda dengan anak normal. Konsep diri yang positif biasanya akan ditunjukkan tunagrahita dengan sikap tidak akan ragu untuk dapat 
membuka diri dan menerima masukan dari luar, keberanian mengemukakan pendapat, cenderung memiliki motivasi tinggi untuk mencapai prestasi, mampu mengaktualisasikan potensinya, dan mampu menyelaraskan diri dengan lingkungannya. Sebaliknya tunagrahita yang memiliki konsep diri negatif adalah tunagrahita sebagai individu yang tidak dapat mengevaluasi makna yang terkandung dalam situasi yang diterimanya (penilaian kognitif). Situasi tersebut akan menimbulkan suatu tekanan dan ancaman terhadap kesejahteraan dirinya sehingga tidak dapat menyelesaikan persoalan dengan tepat.

Berkembangnya konsep diri tidak lepas kaitannya dengan perlakuan orang tua. Bila tunagrahita meyakini bahwa orang-orang yang penting baginya menyayangi mereka, maka mereka akan berpikir secara positif tentang diri mereka. Begitu juga sebaliknya bila orang yang penting bagi dirinya tidak menyenanginya maka ia akan berpikir negatif terhadap dirinya. Jadi gambaran mengenai konsep diri tunagrahita dibentuk dari bagaimana individu itu memandang dirinya sendiri dan melalui pengalaman khususnya pengalaman dari orang-orang terdekat dan yang memberikan arti bagi tunagrahita tersebut.

\section{Kemampuan Komunikasi Verbal Tunagrahita}

Perkembangan bahasa anak tunagrahita berbeda dengan anak normal lainnya, karena tunagrahita mengalami keterlambatan dalam perkembangan bahasa atau bicara. Hasil temuan data di lapangan mendapatkan fakta yang sama, anak tunagrahita yang menjadi informan penelitian mengalami gangguan ujaran (speech disorder) atau gangguan bahasa (language disorder). Gangguan ujaran tersebut berupa masalah dalam artikulasi yang menyangkut substitusi (satu bunyi diganti dengan bunyi lain) dan omisi atau menghilangkan bunyi sama sekali. Jenis gangguan lainnya mencakup keadaan gagap dan suara parau atau kelainan volume dan warna suaranya, namun semua hal tersebut menjadi bentuk komunikasi verbal yang khas pada tunagrahita dan yang membedakannya dengan anak normal lainnya.

Bentuk komunikasi verbal informan tunagrahita dengan penggunaan kata-kata terangkum dalam Tabel 2.

Tabel 2

Bentuk Komunikasi Verbal Dengan Penggunaan Kata-kata

\begin{tabular}{ccl}
\hline No. & Nama Inisial & \multicolumn{1}{c}{ Bentuk Komunikasi Verbal } \\
\hline 1 & MZ & Artikulasi kurang jelas \\
2 & AL & Artikulasi kurang jelas dan omisi \\
3 & GU & Artikulasi kurang jelas \\
4 & RA & Gagap \\
5 & MH & Artikulasi kurang jelas dan suara parau \\
6 & MA & Artikulasi jelas \\
\hline
\end{tabular}

Sumber: Hasil Penelitian April 2009- Oktober 2009 
Tabel 3

Bentuk Komunikasi Verbal Dengan Menggunakan Tulisan

\begin{tabular}{ccl}
\hline No. & Nama Inisial & \multicolumn{1}{c}{ Tulisan } \\
\hline 1 & MZ & Ada huruf yang hilang \\
2 & AL & Dikte banyak huruf yang hilang dan penulisan kata terbalik \\
3 & GU & Banyak huruf yang hilang \\
4 & RA & Jelas \\
5 & MH & Menulis kata terbalik \\
6 & MA & Ada huruf hilang \\
\hline
\end{tabular}

Sumber: Hasil Penelitian April 2009 - Oktober 2009

Selain itu dari hasil pengamatan yang terjadi di lapangan, tunagrahita menggunakan bahasa verbal cukup singkat hanya satu kata atau dua kata atau menggunakan kalimat tunggal, serta selalu melakukan pengulangan, berikut pernyataan guru, yaitu Muzaidi: "Pada umumnya anakanak disini kalau berbicara menggunakan kata yang singkat, dan kalimat tunggal, atau memiliki perbendaharaan kata terbatas, ini mungkin karena rutinitas yang selalu sama" (Wawancara dengan Muzaidi, 18 Juni 2009).

Pernyataan Muzaidi tersebut dipertegas oleh Darwis seperti pernyataannya berikut ini: "Kata-kata yang digunakan anak tunagrahita tidak bervariasi, contohnya menyebutkan dirinya sendiri selalu dengan namanya, bukan saya atau kamu, demikian pula ketika menyebutkan temannya selalu menyebut namanya bukan kamu atau sebagainya" (Wawancara dengan Pak Darwis, 25 Juni 2009).

Penggunaan tulisan pada informan ketika berkomunikasi verbal bervariasi, sebagian besar informan ketika menulis ada satu huruf yang hilang. Informan tersebut yaitu MZ, GU, MA dan AL, hanya saja kondisi AL agak berbeda ia biasanya ketinggalan satu huruf apabila didikte, demikian dituturkan Darwis guru kelas AL:
"Kalau menulis biasa AL tidak ada masalah, hanya saja kalau dikte pasti ada saja huruf yang tertinggal" (Wawancara dengan Darwis guru kelas, 12 September 2009).

Sedangkan MH jika menulis sering sekali terbalik, seperti mengatakan kata saya menjadi "yasa" mengatakan kamu jadi "muka". Informan yang tidak mengalami hambatan dalam komunikasi verbal dengan penggunaan tulisan adalah RA. Seperti dituturkan Agus guru kelas RA kepada peneliti: "Memang $R A$ itu tulisannya sangat jelas dibandingkan teman-teman yang lainnya" (Wawancara dengan Agus guru kelas, 12 September 2009).

\section{Kemampuan Komunikasi Nonverbal Tunagrahita}

Komunikasi nonverbal merupakan komunikasi yang menggunakan pesan-pesan nonverbal. Istilah nonverbal biasanya digunakan untuk melukiskan semua peristiwa komunikasi di luar kata-kata terucap dan tertulis. Dalam kenyataannya komunikasi nonverbal dapat saling melengkapi dalam komunikasi yang kita lakukan sehari-hari. Begitu pun bagi anak tunagrahita mereka mengirim pesan-pesan nonverbal. Adapun komunikasi nonverbal tunagrahita dalam penelitian ini secara garis besarnya, terdiri 
dari: 1) artifactual/penampilan, 2) haptics/sentuhan, 3) kinesics/gerakan tubuh, 4) paralinguistics/vokalik, dan 5) proxemics/pengaturan jarak.

Komunikasi nonverbal secara artifaktual yang ditemukan pada keseharian anak tunagrahita di SDLB Negeri 041 Bangkinang adalah dari penampilan pakaian mereka dan aksesoris lainnya. Pada sebagian informan tunagrahita artifactual/penampilan hampir sama dengan anak normal lainya, sebagain besar tertata rapi. Penggunaan haptics atau sentuhan sebagai tanda penghormatan atau sebagai cara untuk memulai percakapan, misalnya dengan bersalaman, merangkul tangan sesama tunagrahita sebagai ungkapan ikut terlibat dalam situasi komunikasi. Kinesics atau gerakan tubuh, ditunjukkan melalui kontak mata, ekspresi wajah, isyarat, dan sikap tubuh karena gerakan tubuh tersebut. Sebagian besar informan tunagrahita saat berbicara dengan partisipan guru bahkan beberapa dengan teman atau sesama tunagrahita menghindari kontak mata dengan cara lebih banyak menunduk. Namun demikian ketika proses belajar mengajar ada beberapa informan tunagrahita dengan kontak mata yang terfokus pada objek yang menjadi perhatiannya, dengan memiringkan kepala ke sudut ruangan dimana di sana ada guru yang sedang menjelaskan pelajaran dengan tangan diletakan di telinga. Ada pula informan tunagrahita saat berkomunikasi dengan guru, kontak mata terfokus pada guru tetapi dengan ekspresi wajah yang datar, sesekali ia menganggukan kepala untuk menjawab pertanyaan yang mengandung arti " $y a$ " atau setuju dan sebaliknya, ketika ia tidak setuju atau mengatakan "tidak" ia akan menjawab pertanyaan tersebut dengan menggelengkan kepala.

Untuk komunikasi nonverbal vokalik atau paralinguistics, sebagian informan tunagrahita mengalami hambatan dalam berbicara bahasa nonverbal vokalik yaitu artikulasi yang tidak jelas, penggunaan suarasuara pengisi ('mm', ‘e', 'o', “um”), berbicara terlalu cepat, sehingga ada beberapa kata yang akhirnya tidak diucapkan lengkap dan tidak jelas, dan ini membuat penafsiran isi pesan yang salah. Komunikasi nonverbal dengan proxemics disampaikan melalui pengaturan jarak dan ruang. Sebagai informan tunagrahita jika berada dalam situasi formal atau dengan guru yang mempunyai jenis kelamin berbeda akan menjaga keintiman melalui jarak melalui posisi duduk atau berdiri.

\section{Pembahasan}

Berbicara mengenai perilaku komunikasi verbal dan nonverbal dilihat dari perspektif interaksi simbolik, maka tidak dapat dipungkiri bahwa setiap anak tunagrahita memiliki pola komunikasi yang berbeda. Hal tersebut tidak terlepas dari adanya perbedaan realitas yang dihadapi oleh mereka dimana setiap tunagrahita memberi pemaknaan dan penafsiran yang berbeda atas realitas yang dihadapinya. Dalam batas-batas tertentu, masalah yang dihadapi tunagrahita akan berbeda antara lingkungan keluarga dengan lingkungan sosial terutama lingkungan sekolah, di lingkungan sekolahpun semakin dirasakan perbedaannya ketika mereka bersekolah di komunitas SD umum dengan SDLB. Masalah yang dihadapi tersebut berimplikasi pada perubahan sebagian pola komunikasi. Hal ini relevan dengan pandangan interaksi simbolik Mead (Mulyana, 2002) yang mengasumsikan manusia sebagai peserta komunikasi (komunikator) bersifat aktif, reflektif dan kreatif menafsirkan, menampilkan perilaku yang rumit dan sulit diramalkan.

Demikian pula setiap tunagrahita melakukan perilaku komunikasi baik verbal maupun nonverbal yang berbeda sesuai dengan nilai-nilai, kebutuhan subjek dan motif subjek dalam menghadapi persoalan hidup, kondisi ketunagrahitaan yang berbeda dan lingkungan yang berbeda, sekaligus memaknakan hal tersebut dengan cara yang berbeda pula. Perbedaan inilah yang membuat fenomena komunikasi tunagrahita terlihat lebih beragam dan dinamis.

Dari perilaku komunikasi verbal dan nonverbal tunagrahita dengan tinjauan interaksi simbolik didapatkan 2 tipe 


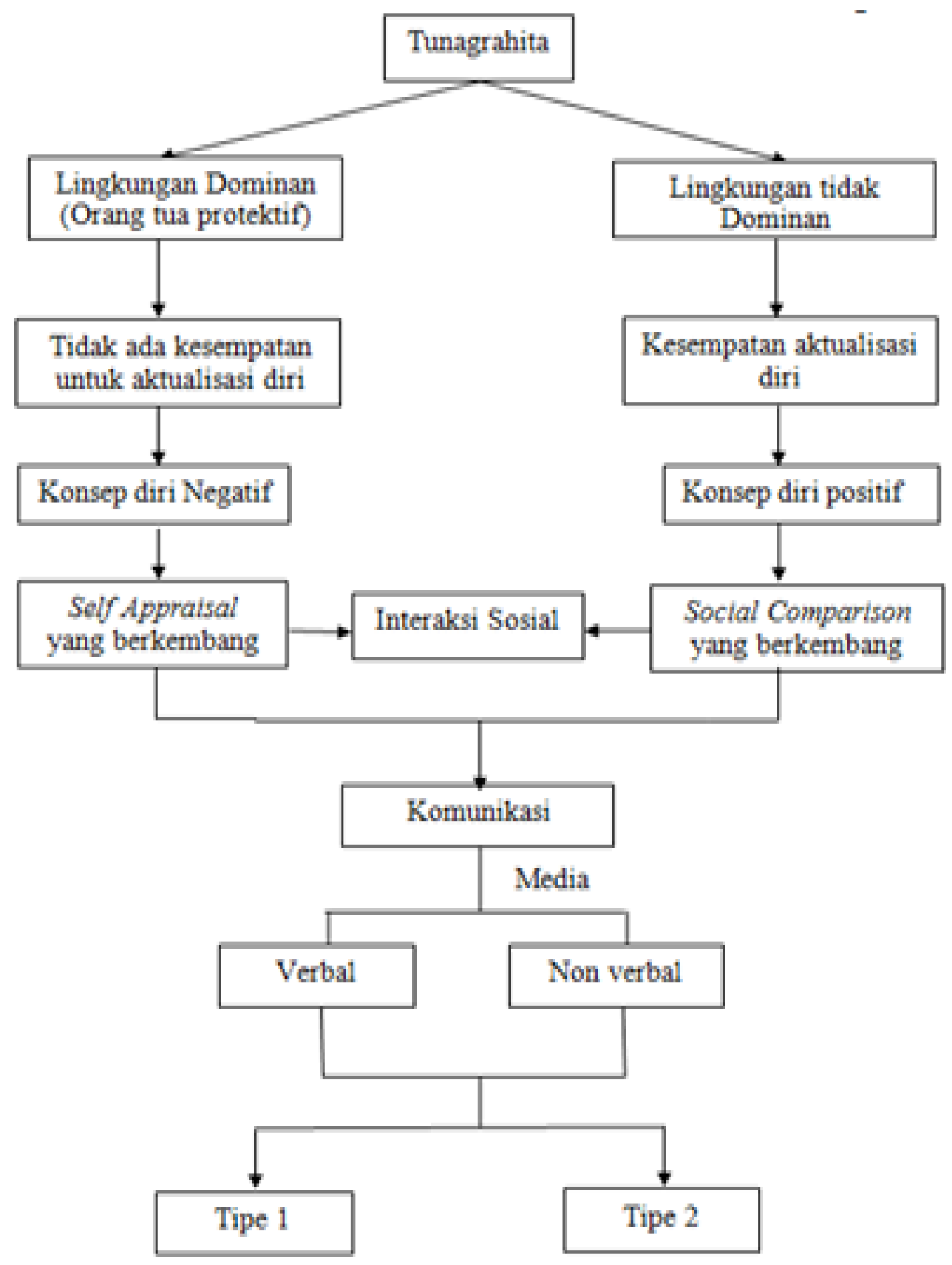

(Sumber: Dikonstrusikan berdasarkan hasil penelitian, April 2009 - Oktober 2009)

Gambar 1

Pola Komunikasi Verbal dan Nonverbal Tunagrahita 
komunikasi yang khas yang ditemukan pada informan, yaitu: (1) Tipe 1: informan yang mempunyai komunikasi verbal aktif dan nonverbal cukup responsif; (2) Tipe 2: informan yang mempunyai komunikasi verbal aktif dan nonverbal sangat responsif.

Dikatakan aktif, apabila informan sering menggunakan komunikasi verbal tersebut tentunya dengan keterbatasan penggunaan komunikasi verbalnya. Informan dalam penelitian ini umumnya aktif menggunakan bahasa verbal ketika berada dalam situasi informal atau situasi yang dirasakan nyaman. Istilah komunikasi nonverbal cukup responsif apabila informan menggunakan satu atau dua unsur komunikasi nonverbal dan sangat responsif apabila informan mengggunakan seluruh unsur komunikasi nonverbalnya.

Informan tunagrahita dengan tipe 1, dalam interaksi sosial aktif menggunakan komunikasi verbal dan memanfaatkan atau menggunakan komunikasi nonverbal, juga untuk menyatakan pesan atau mempertegas pesan yang ingin disampaikan kepada orang lain hanya saja variasi penggunaan bahasa nonverbalnya terbatas, hanya satu atau dua saja. Sedangkan tipe 2, informan tunagrahita aktif menggunakan bahasa verbalnya dan menggunakan bahasa nonverbal dengan bervariasi.

Namun apapun tipe komunikasi informan tunagrahita, merupakan bentuk komunikasi yang ingin diekspresikan baik sengaja atau tidak sengaja agar orang lain mengetahui keadaan emosi atau perasaan dan apa yang mereka pikirkan, dan tentunya dengan pola komunikasi yang khas yang dimiliki informan sebagai penyandang tunagrahita. Seperti yang dikatakan oleh DeVito (1997) bahwa tujuan manusia berkomunikasi adalah untuk penemuan diri, untuk berhubungan, untuk meyakinkan, dan untuk bermain. Jadi, komunikasi merupakan kebutuhan pokok manusia, termasuk bagi anak dengan keterbatasan tertentu seperti pada penyandang tunagrahita. Namun terlepas apakah anak normal atau anak tunagrahita mempunyai tujuan yang sama ketika melakukan komunikasi yaitu agar kebutuhannya terpenuhi. Dilihat dari perilaku komunikasi verbal dan nonverbal berdasarkan interaksi simbolik secara diagramatik yang digambarkan pada Gambar 1.

\section{PENUTUP}

\section{Simpulan}

Berdasarkan tujuan dan uraian dari hasil penelitian tentang perilaku komunikasi verbal dan nonverbal anak tunagrahita dengan pendekatan interaksi simbolik dapat disimpulkan sebagai berikut: Konsep diri anak tunagrahita informan dilihat dari kemampuan berinteraksi di lingkungan SDLB Negeri 041 Bangkinang dipengaruhi oleh significant other yang dikategorikan menjadi dua, yaitu: konsep diri positif tipe social comparison dan konsep diri negatif tipe self appraisal. Konsep diri positif social comparison terbentuk dari apa yang dirasakan informan mengenai dirinya sendiri dengan apa yang dinilai oleh orang lain terhadap dirinya. Konsep diri negatif tipe self appraisal di mana konsep diri tidak sepenuhnya berkembang karena informan tidak dapat mengekspresikan diri disebabkan yang berkembang adalah pola-pola perilaku yang paling dominan yaitu orang tua.

Komunikasi verbal anak tunagrahita dalam berinteraksi di lingkungan SDLB Negeri 041 Bangkinang bersifat aktif dengan defisit bahasa yang terjadi. Komunikasi umumnya menggunakan kalimat yang sederhana, selalu menggunakan kalimat tunggal, melakukan pengulangan suku kata. Selain itu terjadi masalah pengucapan seperti; pengucapan yang tidak jelas, kualitas suara yang berat dan ritme bicara yang cepat, omisi atau menghilangkan satu huruf, salah mengucapkan bunyi kata, terbalik mengucapkan kata, serta gagap.

Komunikasi nonverbal anak tunagrahita dalam berinteraksi di lingkungan SDLB Negeri 041 Bangkinang bersifat komunikatif. Komunikasi nonverbal dapat dilihat melalui penampilan, haptik, kinesik, proximity, dan vokalik/paralinguistik yang memiliki kemiripan. Komunikasi nonverbal tersebut digunakan untuk menyampaikan 
pesan, melengkapi atau menegaskan pesan verbal. Bentuk komunikasi nonverbal yang dilakukan tunagrahita dapat mengindikasikan sebagai reaksi suka tidak suka, mau tidak mau, mengerti tidak mengerti, tahu tidak tahu, dan lain sebagainya.

\section{Saran}

Dari simpulan di atas maka disarankan, orangtua ataupun guru dan saudara terdekat tunagrahita ikut memberikan dukungan moril dan stimulan seperti menanyakan aktivitas yang dilakukan, menanyakan apakah hari ini menyenangkan atau sebaliknya jika diperlukan memberikan bantuan, dan mengajarkan anak untuk lebih membuka diri terhadap orang lain. Sehingga anak tunagrahita terbiasa untuk terbuka dan mau mengomunikasikan apapun yang dia rasakan.

Untuk pihak sekolah terutama guru hendaknya melakukan pendekatan personal untuk melatih verbal anak tunagrahita, tidak hanya ketika mengajar tetapi jika dimungkinkan di luar jam pelajaran sehingga tidak ada jarak antara guru dan anak didik tunagrahita. Hal ini memungkinkan anak untuk berani mengomunikasikan berbagai hal.

Selain itu guru ketika memberikan materi pembelajaran tidak menitikberatkan pada ranah kognitif dan psikomotor saja, ranah afektifnya juga harus dilatih. Salah satu untuk memulai proses pengembangan pembelajaran ranah afektif yaitu guru harus lebih peka dan responsif dengan bahasa nonverbal yang ditunjukkan siswa didiknya.

\section{DAFTAR PUSTAKA}

Basrowi \& Sukidin. (2002) Metode Penelitian Kualitatif Perspektif Mikro. Surabaya: Insan Cendekia.

Delphie, Bandi. (2006) Pembelajaran Anak Tuna Grahita. Bandung: Refika Aditama.

DeVito, Joseph A. (1997) Komunikasi Antar Manusia. Edisi Kelima. Jakarta:
Professional Books.

Fitts, William H., (1984) The Self Concept And Self Actualization. Research Monograph, No.3, Los AngelesCalifornia: Western Psychological Service.

Kuswarno, Engkus. (2009) Metodologi Penelitian Komunikasi:

Fenomenologi: Konsepsi, Pedoman dan Contoh Penelitiannya. Bandung: PT. Remaja Rosdakarya.

Littlejohn, Stephen W. (1996). Theories of

Human Communication. USA:

Wadsworth Publising Company.

Moleong, Lexy J. (2007) Metodologi Penelitian Kualitatif. Bandung: Remaja Rosdakarya.

Mulyana, Deddy. (2005) Ilmu Komunikasi Suatu Pengantar. Bandung: Remaja Rosdakarya.

Mulyana, Deddy. (2006) Metodologi Penelitian Kualitatif. Bandung: Remaja Rosdakarya.

Rakhmat, Jalaluddin. (1999) Psikologi Komunikasi. Bandung: Remaja Rosdakarya.

Somantri, Sutjihati. (2007) Psikologi Anak Luar Biasa. Bandung: Refika Aditama.

Tubbs, Stewart L \& Moss, Sylvia. (2005) Human Communication PrinsipPrinsip Dasar. Deddy Mulyana (ed). Bandung: Remaja Rosdakarya.

\section{Internet:}

Alimin, Zainal. (2007). Pengajaran Bahasa Bagi Anak Tunagrahita. Tersedia dalam <http://zalimin.blogspot.com/2007/07/blogpost.html $>$. Weblog [online] Diakses tanggal 20 Oktober 2008.

Lanniari.(2007). Pesan Nonverbal dalam Proses Pembelajaran Anak Retardasi Mental Ringan di Kelas.Tersedia dalam

http://phierda.wordpress.com $>$ diakses tanggal 23 Oktober 2008.

Rochyadi, Endang dan Didi Tarsidi. (2008) Bahasa dan Ketunagrahitaan. 
$<$ http://e-

rochyadi.blogspot.com/2008_04_01_a

rchive.html $>$. Diakses tanggal $\overline{2} 8$

Oktober 2008.

Informasi Pelayanan Pendidikan bagi Anak
Tunagrahita. $<$ http://www.ditplb.or.id/ 2006/index.php?

menu $=$ profile $\&$ pro $=45>$. Diakses tanggal 11 November 2008. ..http://elib.unikom.ac.id 